\title{
The Construction and Verification of Decent Work Indicators System Based on Questionnaires of 2000 Employees
}

\author{
Yan Xu ${ }^{1, a, ~}$, Dun Liu ${ }^{2, ~ b}$ \\ ${ }^{1}$ School of Economics and Business Administration, Beijing Normal University, Beijing, China \\ ${ }^{2}$ School of Economics and Management, Beijing Jiaotong University, Beijing, China \\ a2522706406@qq.com, blliudun@bjtu.edu.cn \\ * Corresponding author
}

Keywords: Decent Work, Indicators System, Status Analysis.

\begin{abstract}
Based on the preliminary qualitative analysis, this paper establishes an indicators system of decent work consisting of 6 primary indicators and develops corresponding measurement scales. Based on the questionnaire data from 2000 employees in Beijing, the analysis reveals that the measurement model shows high validity and fitness, and the measurement model invariances test verifies that the same indicator weights specification applies to different employees.
\end{abstract}

\section{Introduction}

"To realize the highly-qualified and more sufficient employment" is not only the purposes of social policies which officially came out in the report by the Communist Party of China in 2017, but also the pursuit of the governments and the public all over the world. In the 50s' last century, the quality of employment used to be expressed in different phrases, such as, "quality of working life", "job satisfaction”, "job characteristics”, "quality of work", "quality of employment”[1], meant to explain different layers, views and emphasizes. On the meeting of the 87th International Labor Conference that was held on June, 1999, the director of the ILO, Juan Somavia promoted "decent work for everyone" as the primary goal for the ILO. He insisted that the decent and productive working opportunities should be provided for people in spite of gender, under the premise of freedom, equality, safety and the protection of human rights.[2] From then on, decent work has been an expression, a political goal and academic theme to value the quality of employment. Decent work is not only embodied the justice and humanistic concern, but also regarded as the aim of "to make the globalization more fair", by means of communication among the labor, the capital and the government. As a common goal, decent work is wildly accepted by governments, experts and unions and so on.

Decent work or high-qualified employment is one of primary components for the "Good Life". What's more important, it has been testified by lots of research which proved that decent work could promote the level of social benefit. As a view of macro-economy, decent work has an obvious effect on the stability of the labor market[3], overall economic competitiveness[4]; human development index[5]. For the micro level, the quality of employment is favorable prediction index for the investment of employees, commitment to the organizations, suggestive behaviors, working performance and even the creative capabilities. However, with the deepening of the globalization and liberalization of economy, especially since the global financial crisis in 2008, the increasing proportion of the informal employment or precarious work, the big-scale substitute of AI, the wide expansion of the gap of wage earnings, the condition of decent work has been severe challenged in all the countries. How to understand the antecedences and consequences of the decent work, also the mechanism between the factors, and how to value, inspect and raise up the level of the decent work, have been an important subject which was brought out in the public management and enterprises operation. 
In this article, a scale of seven primary indexes is introduced with the strict process of grounded theory. Based on the sufficient interviews, the framework of indicator system was designed to format a questionnaire which contains 6 primary indicators, and also the score scale to for each indicator. Over 2000 samples informants were asked to complete questionnaires in order to testify the rationality and the universality of the indicator system.

\section{Method and Data}

Many international organizations and scholars have tried to construct the evaluation indexsystem, according to their understanding of the decent work. Present evaluation index system can be divided into three classes based on their basic philosophies, for example the choice of the formation, whether from top to bottom, or the opposite, and the patterns of evaluation index, including objective tatistical indicators and subjective self-assessment indexes.

The first class called 'Theoretical Objective Statistical Indicators'. From top to bottom, the indicators are formatted according to the expressions of ILO, composed of four strategic goals, including basic principles and rights, employment, social protection and social conversion, and constructed by relative theories. The representative academic achievements include the official evaluation index system with 11 primary indicators which was confirmed in 2003, and revised in 2008, articles written by Anker[6], Bescond[7], Bonnet[8], Ghai[9], published in International Labor Review in 2003. The advantages of such system are the faithfulness to the initial expressions of ILO, and easily used to value and compare the level of decent work for cross-countries and industries. The disadvantages are that will be easily affected by the limit of availability of statics and comparison of countries. What's more important, it neglects the fact that decent work is a subjective psychology constructing which could differ among persons. That is meant to say under the same objective conditions, different person will have different perception.

The second class can be described as the combination of the subjective and objective index systems. For this class, although it is also formatted from the top to the bottom theoretically, it gives considerations into the combination of two classes. The representative results are the European Working Condition Survey made by European Foundation, once every four year. The indicator system collects statics by questionnaire survey, which is composed by two parts. One part is usually about the wage income; working intense, technical training and so on, that is questioned by the mode of objective static or T/F answers. The other part is about the occupational vision, working atmosphere and overall satisfaction that is answered according to the questionees' subjective affection to give relative scores. Because this system remains the objective indicators as the main position, it still neglects the psychological attributes of decent work and sense-making of the labors. Some scholars suggest using the scheme of "Psychology of Working" to make the research and to build the bridge between the objective and subjective system.

The third one is the subjective self-assessment indicator system based on experiences, which can be looked upon as the response to the disadvantages above. Under this idea, the research begins from numeral interviews to labors, to extract the attributions or factors in common of interviews. Then, according to the indicators to make up the scale of subjective affection of decent work, and which will be sent out as the questionnaire. As the following tasks, the factor analysis of the collected questionnaires is used to testify the rationality of the index system. Although such methods used to be mostly adopted in the evaluation of "job satisfaction" during early periods, the research which strictly aimed at decent work can be found only by minor civil scholars in China. The representatives articles including Tao Qing, Yuelan Ding and Li Zhou, Wei-de Huang and Lin-yang Yue, Cheng Yang who all made investigation in labors working in different districts and industries.

In my opinion, the subjective self-assessment indicator system based on experiences corresponds with the nature of the decent work. Even if it couldn't replace the concept, it can be used to the indispensable reference and supplement of the objective indicators system. However, there isn't subjective indicator semen which could be widely accepted in the academic circle which is caused by three deficiencies in the research. Firstly, the research lacks the basement of qualitative study, which 
can be judged by the fact that most of articles are written only by less view samples, or not according to the norms.

As the result of the complete comparison of the forehead classes, I choose the grounded theory created by Glazer \& Strauss[11] to preinstall the indicator system of the decent work. By means of observation, interaction and collection of interviews, substantive data could be achieved. After that, coding, classifying are the necessary stages to conceptualize the data. With the records of interviews and use of software Nvivo 11.0, we analyzed the data and format 6 structural dimensions that is decent perception on wage incomes, job protection working environment, occupational development and social position.

\section{The Construct of Decent Work Perception}

The first dimension is Decent Perception on Wage Incomes. For this, two parts should be taken into account. One part is the absolute amount of the income for employees which can realize the decent life. Under this consideration, income for employees should catch up with the rise of living cost. The other part is the relative relation of the input reward ratio between the employee's and others'. In other words, it is the fairness, which also could be divided into inner fairness and outer fairness. The former fairness is affected by the inner comparison between the employee and his colleagues. The latter one is percept by the comparison from the employees working in similar positions.

The second dimension is Decent Perception on Job Protection. This dimension is designed to assess the safety perception provided by employees' jobs. It includes not only the "social protection" promoted by ILO, but also the stability of the job. The decent perception on Job Protection means a working person has a stable and formal job which is able to provide him a stable life.

The third dimension is Decent Perception on Working Environment. For the assessment of working environment, we use two fields, physical and interpersonal, to distinguish the objective indicators and subjective perception. The facilities related to working, such as working protection, occupational health, working meals, accommodation, leisure districts, are defined to the physical environment. We classify a series of social relationship into interpersonal environment. For example, most of employees intent to give high assessment for the organizational atmosphere in which they can construct the trust for the colleagues and leaders and own the feeling of family members.

The fourth dimension is Decent Perception on Working Intense. Working intense is the pressure for an employee to bear in order to get the job. The balance between job and life is the main factors which affect the decent work evaluation. Most of informants expressed their negative feelings about overtime working. They said, "When I leave my working place for home, the only thing I want to do is to relax myself or have time with my family, not to continue working at home."

The fifth dimension is Decent Perception on Occupational Development. According to two-factor theory by Herzberg, occupational development is the incentive factor for working satisfaction ${ }^{[12]}$. The perception is achieved by two conditions. One is the skillful standard for the job which could make persons feel happy. The other is the value of the job, which could realize personal achievement.

The sixth dimension is Decent Perception on Social Position. Social position is defined as the rights and the valuation by social relationship. People tend to feel satisfied when they own enough supporting rights to take an active part in the social affairs. From this point, it is similar to "social dialogue” by ILO, such as employee participation in management and collective negotiation with the capital owners. For another view, employees feel proud of themselves when they get acknowledgment from family members and social relationship. Among interviews, an informant said, "I am satisfied with my job because whenever I introduce the brand name of my company, others always show respects to me.”

\section{The Scale of Six Dimensions}

Based on six dimensions, we design the questionnaire scale to establish the indicators which could 
be convenient and operable to be measured (shown in Table 1). Five-level scale of Likert was adopted in the scale, including five choices, "totally disagree", "disagree”, "without feelings", "agree”, "totally agree”, which were assigned one score to five scores.

Table 1 Decent Work Perception Dimensions \& Indicator Scale questions

\begin{tabular}{|c|l|}
\hline Dimensions & \multicolumn{1}{|c|}{ Matching questions } \\
\hline $\begin{array}{c}\text { Decent Perception on } \\
\text { Wage Incomes }\end{array}$ & $\begin{array}{l}\text { Q1 I can lead a comfortable life with my present wage incomes. } \\
\text { Q3 Compared with other colleagues, I feel fair about my input and } \\
\text { reward. } \\
\text { Q4 Compared with other persons on the similar working positions, I } \\
\text { feel fair about my input and reward. }\end{array}$ \\
\hline $\begin{array}{c}\text { Decent Perception on } \\
\text { Job Protection }\end{array}$ & $\begin{array}{l}\text { Q5 I feel stable for my job. } \\
\text { Q6 I feel satisfied with my insurance condition. }\end{array}$ \\
\hline $\begin{array}{c}\text { Decent Perception on } \\
\text { Working Environment }\end{array}$ & $\begin{array}{l}\text { Q7 I feel satisfied with the working facilities, such as productive tools } \\
\text { and equipments, also the occupational protection. } \\
\text { Q8 I can get well along with my colleagues and I can trust them. } \\
\text { Q9 I think the communication between leaders and me is fluent and I } \\
\text { can trust them. }\end{array}$ \\
\hline $\begin{array}{c}\text { Decent Perception on } \\
\text { Working Intense }\end{array}$ & $\begin{array}{l}\text { Q10 I can balance my job and my life. } \\
\text { Q11 The frequency of over-time for me is acceptable. } \\
\text { Q12 I feel tired after work. }\end{array}$ \\
\hline $\begin{array}{c}\text { Decent Perception on } \\
\text { Occupational } \\
\text { Development }\end{array}$ & $\begin{array}{l}\text { Q13 I am capable for my job and I can find happiness in it. } \\
\text { Q14 I have clear vision for my future in the company. }\end{array}$ \\
\hline $\begin{array}{c}\text { Decent Perception on } \\
\text { Social Position }\end{array}$ & $\begin{array}{l}\text { Q15 I think my job is full of value and significances for the society. } \\
\text { Q16 I achieve respects from my family members and other persons. }\end{array}$ \\
\hline
\end{tabular}

\section{The Weight of Factors}

To give the weight of factors, we firstly calculate the dimension weight $\left(D W_{i}\right)$ by means of weighting average all the scores inside the dimension, $\mathrm{j}$ represents the dimension, $\mathrm{k}$ presents the amount of indicators inside the same dimension, Wi represents competitive weight, and FSWjk represents the scores of the individual indicator. formulas shown as following:

$$
\begin{aligned}
& W_{i}=D W_{i} / \sum D W_{i}, i=1,2, \ldots, 16 \\
& D W_{i}=F S W_{j k} /\left(F S W_{j 1}+F S W_{j 2}\right), j=1,2, \ldots, 6 ; k=1,2
\end{aligned}
$$

By means of such equations, we got the weight for each dimension (shown in Table2).

With the weight of factors, we can get the statistical description of the level of decent work for employees working in Beijing based on data collected from 2000 samples. The overall score of the level of decent work in Beijing is just above 60, which means the middle level. To find the effects that will induce different level, we make a comparison score with several statistical variances, such as genders, ages, working years, type of organizations and occupations(shown in Table 3).

It is not difficult to find that there is little difference among different groups. However, the differences lie in individual subjective assessment. The score of female is higher than that of male. The elder ages and longer working years of groups' tent to give higher valuation of the work. The employees working in government organizations seem to be more satisfied than other enterprises. The employees with skills give the highest scores for their perception of decent work. From the analysis, the philosophy of subjective indicators construction from bottom to top can be verified to be suitable for the real labor world. 
Table 2 Weight for Decent Work Perception Dimensions

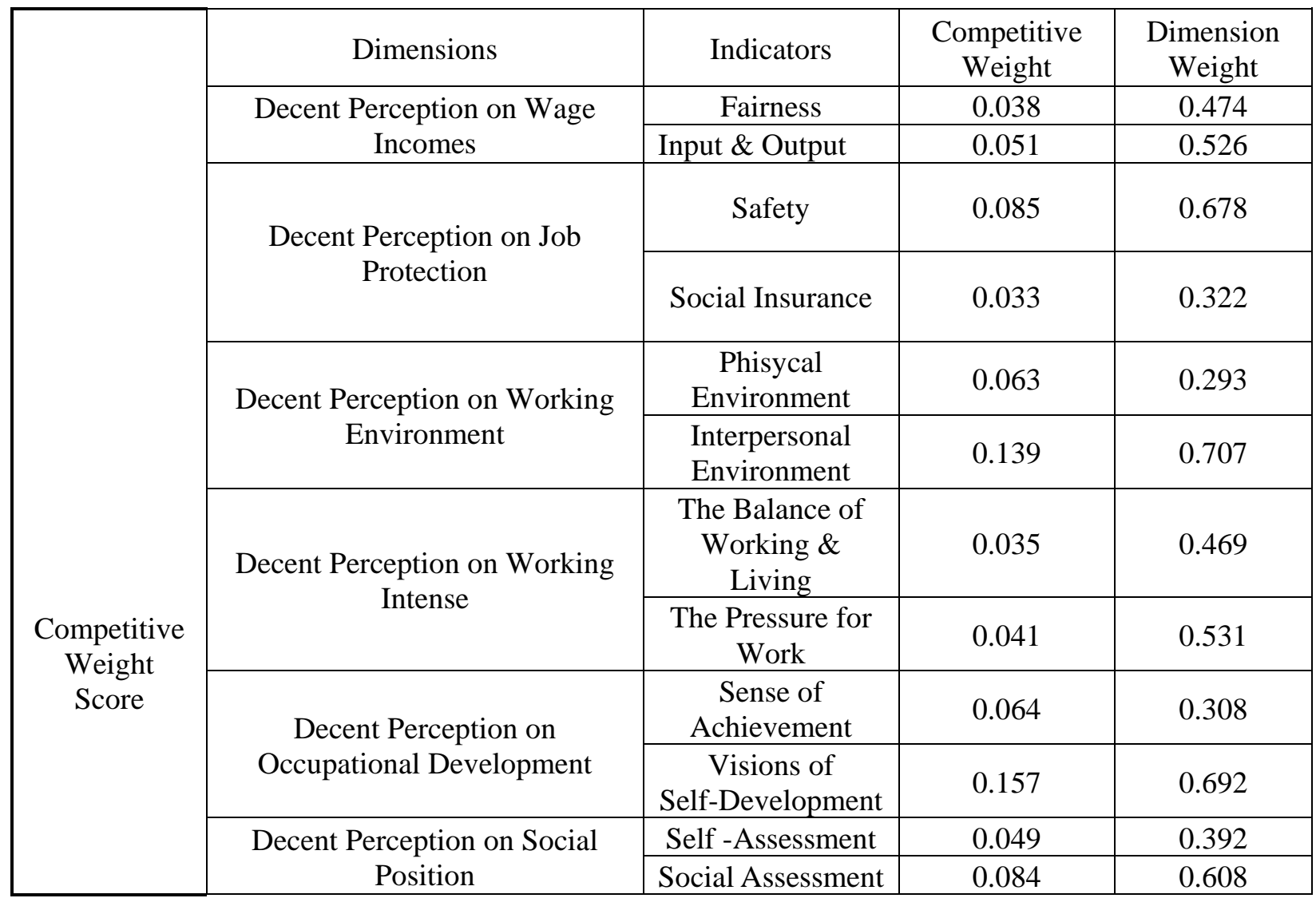

Table 3 Competitive Weight Scores for Different Groups

\begin{tabular}{|c|c|c|c|c|c|}
\hline $\begin{array}{c}\text { The } \\
\text { classificatio } \\
\text { n }\end{array}$ & \multicolumn{5}{|c|}{$\begin{array}{l}\text { Competitive Weight Scores of Different Groups（the overall } \\
\text { average }=62.7, \text { standard deviation between individuals =14.6) }\end{array}$} \\
\hline \multirow{2}{*}{ Gender } & \multicolumn{3}{|c|}{ Male } & \multicolumn{2}{|c|}{ Female } \\
\hline & \multicolumn{3}{|c|}{61.2} & \multicolumn{2}{|c|}{64.0} \\
\hline \multirow{2}{*}{ Age } & 90s' & 80s' & 70s' & 60s' & $50 s^{\prime}$ \\
\hline & 61.4 & 62.2 & 63.1 & 64.6 & 69.3 \\
\hline \multirow{2}{*}{$\begin{array}{c}\text { Working } \\
\text { years }\end{array}$} & Less than 5 & $5-9$ & $10-14$ & $15 \sim 19$ & Above 20 \\
\hline & 61.6 & 61.9 & 62.2 & 63.3 & 65.3 \\
\hline \multirow{2}{*}{$\begin{array}{l}\text { Type of } \\
\text { organization }\end{array}$} & $\begin{array}{c}\text { Governmental } \\
\text { organizations }\end{array}$ & $\begin{array}{c}\text { State-owned } \\
\text { enterprises }\end{array}$ & $\begin{array}{l}\text { Foreign-owned } \\
\text { enterprises }\end{array}$ & $\begin{array}{c}\text { Private } \\
\text { enterprises }\end{array}$ & others \\
\hline & 64.5 & 61.8 & 63.1 & 62.7 & 62.3 \\
\hline \multirow{2}{*}{$\begin{array}{c}\text { Type of } \\
\text { Occupation }\end{array}$} & $\begin{array}{l}\text { First-line } \\
\text { employees }\end{array}$ & $\begin{array}{c}\text { Management } \\
\text { employees }\end{array}$ & $\begin{array}{c}\text { Professional } \\
\text { technicians }\end{array}$ & Officials & others \\
\hline & 58.8 & 62.6 & 65.1 & 63.8 & 61.9 \\
\hline
\end{tabular}

\section{Conclusion}

For most people, work means a lot to their lives, the attainment of Decent work is obviously a worthy policy objective in its own value. From the foregoing quantitative research based on sufficient interviews, and analysis of data for a balanced mix of 6 dimensions to indicate the level of decent work, it is also clear that the complete indicator system is very necessary in pursuit of that objective. Decent work contributes simultaneously to human development, to economic growth, to the rise of social benefits. The article makes it quite clear that high levels of decent work can be achieved with high wages incomes, complete job protection, good working environment, balanced working intense, 
bright occupational development and respective social position. Although the relative performance of different districts or industries is sensitive to the type of index used to measure decent work, the sound and balanced social policies, humanized working scheme, safe conditions for work are among the significant factors which rank the high valuation of decent work.

\section{Acknowledgements}

This research was financially supported by the Academic Foundation of Beijing JiaoTong University for “The Future of Manufacturing, the 'Made in China 2025' Plan”.

\section{References}

[1] B. Burchell, et al., Quality of Employment and Decent Work: Definitions, Methodologies, and Ongoing Debates, Cambridge Journal of Economics, 38 (2014) 459-477.

[2] ILO, The ILO: What It Is, what It Does, http://www.ilo.org/global/about-the-ilo/WCMS_082364/lang--en/index.htm

[3] R. B. Freeman, Job Satisfaction as an Economic Variable, American Economic Review, 68 (1978) 135-141.

[4] P. Egger, Decent Work and Competitiveness: Labor Dimensions as Accession to the European Union, International Labor Review, 142 (2003) 5-27.

[5] L. Ahmed, Decent Work and Human Development, International Labor Review, 142 (2003) 263-271.

[6] R. Anker, et al., Measuring decent work with statistical indicators, ILO Policy Integration Department, Statistical Development and Analysis Unit, Working Paper No.2, 2002.

[7] F. Bescond, et al., Seven Indicators to Measure Decent Work: An International Comparison, International Labor Review, 142 (2003) 179-211.

[8] D. Bonnet, et al., A Family of Decent Work Indexes, International Labor Review, 142 (2003) 213-238.

[9] D. Ghai, Decent Work: Concepts and Indicators, International Labor Review, 142 (2003) 113-145.

[10] D. L. Blustein, et al., Decent Work: A Psychological Perspective, in A. Di Fabio, D. L. Blustein, eds. From Meaning of Working to Meaningful Lives: The Challenge of Expanding Decent Work, Special Issue of Frontiers in Psychology, 7 (2016) 8-16.

[11] A. Strauss, J. Corbin, Basics of Qualitative Research: Grounded Theory Procedures and Techniques, Sage Publications, London, 1990.

[12] F. Herzberg, et al., The Motivation to Work, 2nd ed., John Wiley, New York,1959. 